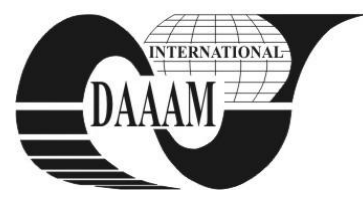

\title{
THE PROPOSAL OF THE METHODOLOGY FOR USING COLLABORATIVE MANAGEMENT IN AN INDUSTRIAL COMPANY
}

\author{
KELEMENOVA, Z[uzana] \& CIBULKA, V[iliam]
}

\begin{abstract}
Rapidly changing conditions in the market confirmed the increasing importance of logistics in the managing of company and shows the need for making partnerships between companies through supply chains. The important part is cooperation between members of supply chains in the supply chain management. This paper introduces the proposal of process of creating the methodology for using collaborative management in the industrial company. The necessity of working within this methodology is published in research and studies. These studies show the connection between the collaboration of management and increasing performance. As a result, a company is more competitive.
\end{abstract}

Key words: integrated logistics, supply chain management, collaborative management, competitiveness

\section{INTRODUCTION}

Logistics is defined as strategic functional management; efficient mass flow of raw materials; stocks and goods with aim to fulfill parametres of time, place, quality; and value that is desired by customers. Integral parts of logistics are flows of information, materials, and finance that link logistics processes by providing goods to customers to ensure many sources (Štůsek, 2007).

The implementation of logistics by the military with accurate planning and supply was an integral part of winning the war. Subsequently logistics was used in the area of production (as a consequence of market liberalization and focusing on customer's requirements). In order to react fast to market changes; produce effectively; and supply goods to the customers effectively, logistics became increasingly important. The integration of all activities had to be secure. From the receipt and stocking of materials to the company, all production processes, to the delivery goods. It is well known today that the next step to increased competitiveness of the company is creating strategic alliances and partnerships. It means creating integrated supply chains. It is important to pay attention to the cooperation between individual elements in the supply chain management. The next vital component to the companies increased competitiveness on the market is the creation of an effective methodology that describes which processes and cooperation relationships are needed to actively manage.

\section{IMPORTANCE OF COLLABORATIVE MANAGEMENT FOR INCREASING COMPETITIVENESS}

The main goal for logistics and supply chain management is to gain a superior competitive position, in terms of the customers demand for goods. Resources for success are extensive on the market, but the basic model shows the connection between three main elements - the company, its competitors and customers. It is important to provide a higher value to customers than the competitor or provide comparable value at a lower cost than the competitor, or in the best case both (Christopher, 2005).

A study of 206 companies in the United Kingdom in 2009 answers the question of how companies improve their logistics and supply chains. The study was conducted by KPMG in cooperation with Lean Enterprise Research Centre (LERC). The results show very important but often contradictory findings. More than $80 \%$ of companies believe that a fully integrated collaborative strategy for supply chain management can markedly increase profit. But on the other side, more than $25 \%$ of companies do not have an employee responsible for supply chain management and more than $50 \%$ of the companies not even a directive for supply chain management. The results from the research suggest that companies are oriented to the saving projects, not to the innovations and providing higher value to customers. Also, companies reported that they are less willing to improve cooperation with partners (Logistics and Supply Chain Report, 2009).

Research shows that in the area of collaboration, supply chains have many places to improve, and companies see strong benefits from active collaboration management.

Another study was conducted in this area which focused to prove a connection between improved performance of a company and collaboration with suppliers and customers in two levels; information sharing and structural collaboration. The study was conducted by Vlerick Lauven Gent Management School by Ann Vereecke and Steve Muylle. Data was collected in 374 companies throughout Europe from 2000 to 2006. Supplying, costs, procurement, flexibility, and quality were set as parametres of performance for this study. Results show that information sharing and structural collaboration have a strong impact on improved performance of companies. This improvement is strongest in the case of shared collaboration between suppliers and customers. Results indicate that collaboration in companies is often chaotic and it is not managed (Vereecke \& Muylle, 2006).

The study mentions a strong link between collaboration and improved competitiveness. It shows that although collaboration is desirable, in many companies it is still not actively managed. Studies do not define clearly which areas and processes of collaboration are needed to orient and effectively manage.

Therefore is important to do research of selected companies in the market that is focused on the present state of collaboration; the companies' expectations; and establishing the conditions that are necessary to effectively manage the collaboration between the company's partners.

\section{THE PROPOSAL OF THE METHODOLOGY FOR USING COLLABORATIVE MANAGEMENT IN THE COMPANY}

The next part shows the proposal of process of how to make a methodology for using collaborative management in the industrial company. This process can be divided into nine related steps. They are shown in the figure 1 . 


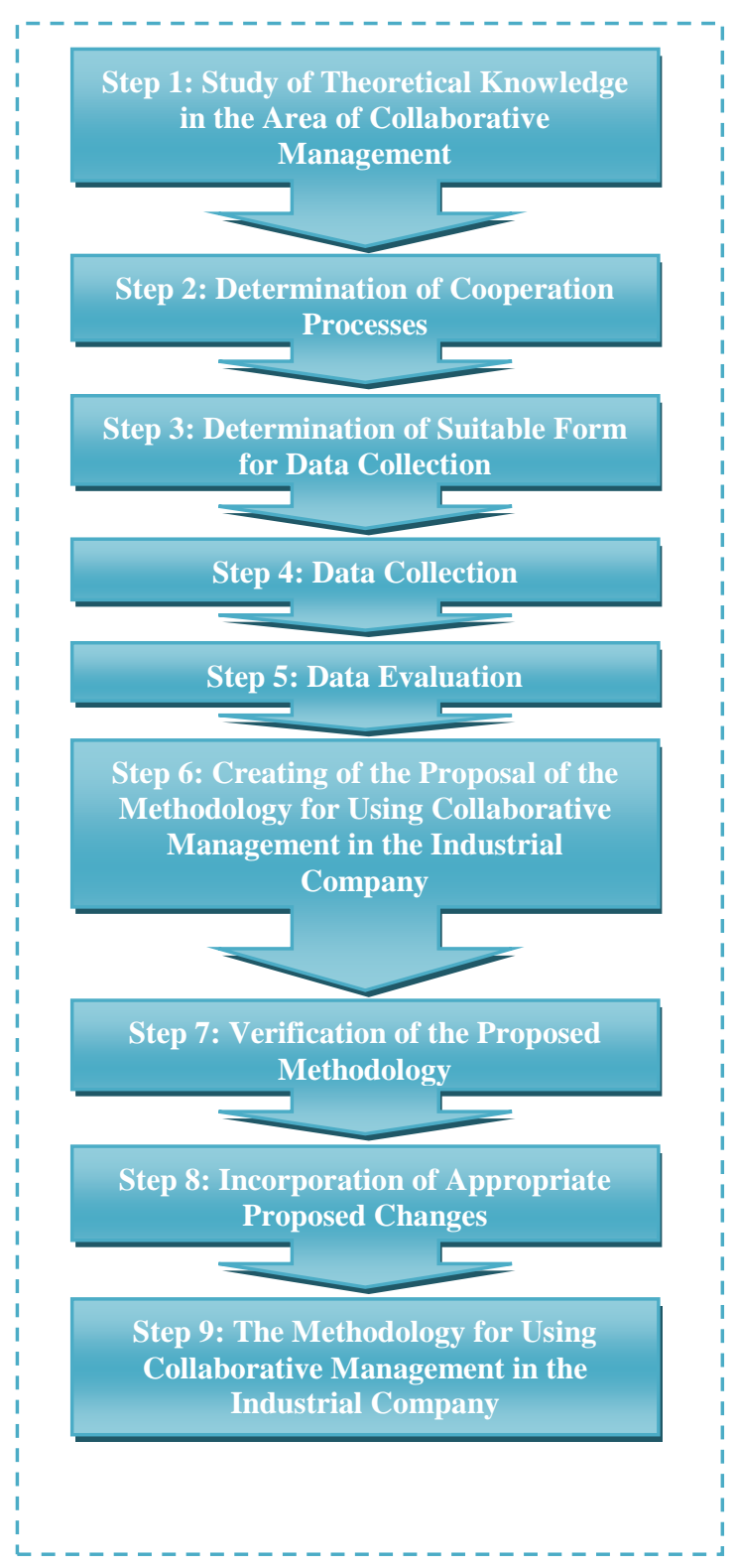

Fig. 1. Process of Creating the Proposal of the Methodology for Using Collaborative Management

The process, shown in figure 1 , describes the creation of the proposal of methodology for using collaborative management from the first step which is theoretical knowledge. You can move to the next step in the case of familiarity with theoretical knowledge and on the base establish areas in which collaboration management brings desired improved competitiveness. The third step includes a statement of suitable forms of data collection. Data collection is divided into two areas for this purpose. First are personal interviews with the chosen companies. A questionnaire is produced on the base of the personal interviews, the second way of data collection. The questionnaire contains about 30 questions and is distributed to the chosen companies (on the basis of focusing on the company and its size). There are questions mapping the present state in the first part of questionnaire. The second part is focused on the desired state of the company as a future and which company wants the benefits of successful collaborative management. There are specific questions oriented to the constrains of cooperation that are established by company (it can be confidential data or withholding data to a supplier that is part of different supply chain,...) in the questionnaire. After finishing the data collection, phase of their handling and evaluation continues.
The proposal of the methodology of using collaborative management in the industrial company on the base of evaluated data is created. This is specific to several areas and processes in the company which has the greatest impact on collaborative management. After the proposal is created, this has to be verified. Verifying is realized with the cooperation of companies that participate on collaborative management and provide data. The proposal of methodology is provided by verifying and commenting. The proposed changes are subsequently justified based on the feedback from companies and incorporated into the final version of the proposed methodology. This is how the methodology of using collaborative management in the industrial company, is designed.

Methodology provides instructions to companies in areas and processes, and how to manage cooperation with partners. This methodology affords the companies significant increases of efficiency to their internal processes and it essentially improves processes of partners in the supply chain. Methodology is divided into two main forms of cooperation which are information sharing and structural collaboration. Cooperation in every form finds itself in all areas and processes of a company. It is mostly cooperation in these activities: market research, product design, sales forecasts, production planning, supply and stocking, production, packaging products, expedition, and service. There are described constrains in the methodology that have to be observed for the successful implementation. They are mostly classified business data, contracts between partners, and precise rules of cooperation.

The main applied of the proposed methodology from the research perspective is the gaining of synergic impact from increasing efficiency of processes of collaborative management on the base of complex using knowledge in this area and detailed review of partnerships in specific companies and conditions.

\section{CONCLUSION}

The main purpose of the proposal of the methodology from using collaborative management is to provide to companies appropriate ways to actively collaborate with management and partners of company. Collaborative management, as its applications confirmed, markedly affects company's performance and improves competitiveness and position in the market. It is important to say that companies see its value but nevertheless do not pay enough attention, so there is still more improvement to come. Suitably chosen strategy of cooperation and its successful implementation can synergistically improve parameters of performance in the company.

It is desirable to implement the proposal methodology in the future in an industrial company and verify its force. On the base of the results can be clearly described impact from every process in which cooperation is managed.

\section{REFERENCES}

Štůsek, J. (2007). Řízení provozu v logistických řet'ezcích (Operations management in supply chains). C. H. Beck, ISBN 978-80-7179-534-6, Prague

Christopher, M (2005). Logistics and Supply Chain Management: Creating Value - Adding Networks. Pearson Education, ISBN 0-273-68176-1, London

Vereecke, A. \& Muylle, S. (2006) Performance improvement through supply chain collaboration in Europe. International Journal of Operations \& Production Management, Vol. 26, No. 11, 1176 - 1198.

***(2009)http://www.kpmg.com/Ca/en/IssuesAndInsights/Arti clesPublications/Pages/LogisticsandSupplyChainReport200 9.aspx - Logistics and Supply Chain Report 2009 Accessed on: $2010-12-20$ 